\title{
UPAYA MENINGKATKAN KEMAMPUAN LITERASI MATEMATIS SISWA MELALUI PENERAPAN MODEL PEMBELAJARAN PROBLEM CENTERED LEARNING (PCL) DI SMA NEGERI 1 ANGKOLA BARAT
}

\author{
Marisa Lusiana Siregar, Wiwik Novitasari, Lisna Agustina \\ Program studi Pendidikan Matematika, FKIP UMTS \\ wiwik.novitasari@um-tapsel.ac.id
}

\begin{abstract}
This type of research is Research Action class (Classroom action Research). While the techniques and data collection tool that is the test, and observations. Mathematical literacy ability test percentage of students on a cycle I was $63 \%$ to $82 \%$ in cycle II. With the amount of the percentage increase in the students' mathematical literacy ability tests of 19\%, activity levels of students learning math increases, it is retrieved from the percentage of $63 \%$ levels of math learning activities cycle I, and $82 \%$ in cycle II rose to $19 \%$ and the ability to manage teacher learning percentage of $74 \%$ in cycle I and $94 \%$ in cycle II, with an increase of 20\%, and the results of this study showed that the model of learning Problem Centered Learning (PCL) can improve mathematical literacy ability of the students in class X IPS 2 SMA Negeri 1 West Angkola.
\end{abstract}

Keywords: Problem Centered Learning (PCL) learning model, literacy

\begin{abstract}
Abstrak
Jenis penelitian ini adalah Penelitian Tindakan Kelas (Classroom action Research).Sedangkan teknik dan alat pengumpulan data yaitu tes, dan observasi. Persentase tes kemampuan literasi matematis siswa pada siklus I adalah $63 \%$ menjadi $82 \%$ pada siklus II. Dengan jumlah persentase peningkatan tes kemampuan literasi matematis siswa sebesar $19 \%$, kadar aktivitas belajar matematika siswa meningkat, hal ini diperoleh dari persentase 63\% kadar aktivitas belajar matematika siklus I, dan 82\% pada siklus II naik menjadi $19 \%$ dan kemampuan guru mengelola pembelajaran persentase sebesar $74 \%$ pada siklus I dan $94 \%$ pada siklus II, dengan peningkatan sebesar $20 \%$, dan hasil penelitian ini memperlihatkan bahwa model pembelajaran Problem Centered Learning (PCL) dapat meningkatkan kemampuan literasi matematis siswa di kelas X IPS 2 SMA Negeri 1 Angkola Barat.
\end{abstract}

Kata kunci : Model pembelajaran Problem Centered Learning (PCL), Literasi Matematis

\section{PENDAHULUAN}

Organisation for Economic Cooperation and Development Mendefenisikan Literasi matematis sebagai kemampuan individu untuk merumuskan, menggunakan dan menafsirkan matematika dalam berbagai konteks. Termasuk kemampuan melakukan penalaran secara matematis dan menggunakan konsep, prosedur, fakta, sebagai alat untuk mendeskripsikan, menjelaskan serta memprediksi suatu fenomena atau kejadian. Oleh sebab itu, siswa tidak cukup hanya memiliki pengetahuan tentang matematika, tetapi siswa harus memiliki pemahaman serta mampu untuk mengidentifikasi setiap permasalahan yang diberikan dalam matematika.

Fathani (2016) mengemukakan bahwa literasi matematika tidak hanya mementingkan pada penguasaan materi, melainkan juga memperhatikan penguasaan pada penggunaan penalaran, konsep, fakta, dan alat matematika dalam pemecahan 
masalah sehari-hari. Literasi matematika membekali siswa dengan kesadaran dan pemahaman tentang peranan matematika di dunia modern. jadi, diperlukan Kegiatan pembelajaran yang dapat meningkatkan kemampuan literasi matematis siswa.

Istarani (2011) menyatakan model pembelajaran adalah seluruh rangkaian penyajian ajar yang meliputi segala aspek sebelum, sedang, dan sesudah pembelajaran yang dilakukan guru serta segala fasilitas yang terkait yang digunakan secara langsung atau tidak langsung dalam proses belajar mengajar. Guru diharapkan mampu memilih model pembelajaran sesuai dengan materi yang disampaikan. Meskipun setiap model pembelajaran memiliki kelebihan dan kelemahan masingmasing dilihat dari berbagai sudut, namun yang penting adalah model pembelajaran manapun yang digunakan harus jelas dengan tujuan yang akan dicapai.

Berdasarkan pengamatan yang dilakukan di SMA Negeri 1 Angkola Barat bahwa guru sudah berusaha untuk mengoptimalkan pembelajaran. Guru masuk tepat waktu dan menggunakan jam pelajaran seefektif dan seefisien mungkin dalam pembelajaran matematika. Guru menyampaikan materi pelajaran dan siswa mendengarkan. Ketika guru selesai menjelaskan pelajaran, guru mempersilahkan siswa untuk bertanya namun siswa cenderung pasif, terlihat dari sedikitnya siswa yang mau bertanya. Ketika guru yang memberikan pertanyaan kepada siswa, hanya sedikit siswa yang bisa menjawabnya dan sebagian lagi lebih banyak diam dan tidak memberikan tanggapan. Sehingga aktivitas kelas yang terjadi didominasi kegiatan mencatat atau menyalin (Asri, 2017).

Hasil ulangan harian siswa yang di evaluasi untuk menguji kemampuan literasi matematis siswa kelas X IPS 2 tahun pelajaran 2017/2018 dengan jumlah siswa 33 orang. Diperoleh hasil tes diagnostik bahwa hanya 10 siswa atau 30,3\% yang tuntas dan 23 siswa atau 69,7\% yang tidak tuntas. Hasil ulangan harian siswa yang di evaluasi untuk menguji kemampuan literasi matematis siswa kelas X IPS 2 tahun pelajaran 2017/2018 dengan jumlah siswa 33 orang. Diperoleh hasil tes diagnostik bahwa hanya 10 siswa atau 30,3\% yang tuntas dan 23 siswa atau 69,7\% yang tidak tuntas.

\section{METODE PENELITIAN}

Penelitian ini merupakan penelitian tindakan kelas (Classroom Action Research). Penelitian tindakan kelas dalam penelitian ini terjadi sebanyak dua siklus dan tiap siklus terdiri dari empat tahap yaitu perencanaan, pelaksanaan, pengamatan, dan refleksi. Penelitian tindakan kelas (PTK) ini dilaksanakan berbentuk spiral artinya penelitian yang dilakukan secara bertahap dan melalui proses sampai tercapainya ketuntasan belajar yang ditentukan dari siklus satu siklus yang berikutnya. Setiap siklus meliputi Perencanaan, Pelaksanaan, Observasi, Refleksi. Langkah pada berikutnya adalah perencanaan, pelaksanaan, observasi, refleksi yang sudah direvisi.

\section{HASIL DAN PEMBAHASAN}

\section{Hasil Penelitian Tindakan Kelas Siklus I}

Hasil penelitian tindakan kelas siklus I diuraikan dalam beberapa tahapan. Adapun tahapan yang dilakukan dalam proses Penelitian Tindakan Kelas (PTK) di kelas X IPS 2 SMA Negeri 1 Angkola Barat yaitu perencanaan tindakan, pelaksanaan tindakan, observasi dan refleksi. Hasil penelitian siklus I di uraikan sebagai berikut:

\section{a. Hasil Tes Kemampuan Literasi Matematis Siswa Siklus I}


Siklus I merupakan pembelajaran dengan pokok bahasan rasio trigonometri. Model pembelajaran Problem Centered Learning (PCL) mulai diperkenalkan pada siswa 
dalam pembelajaran untuk melihat hasil peningkatan kemampuan literasi matematis siswa di SMA Negeri 1 Angkola Barat. Pada siklus I terdiri dari 3 kali pertemuan dilaksanakan tes kemampuan literasi matematis siswa, maka hasil yang diperoleh dari tes tersebut dapat dilihat pada tabel 1 .

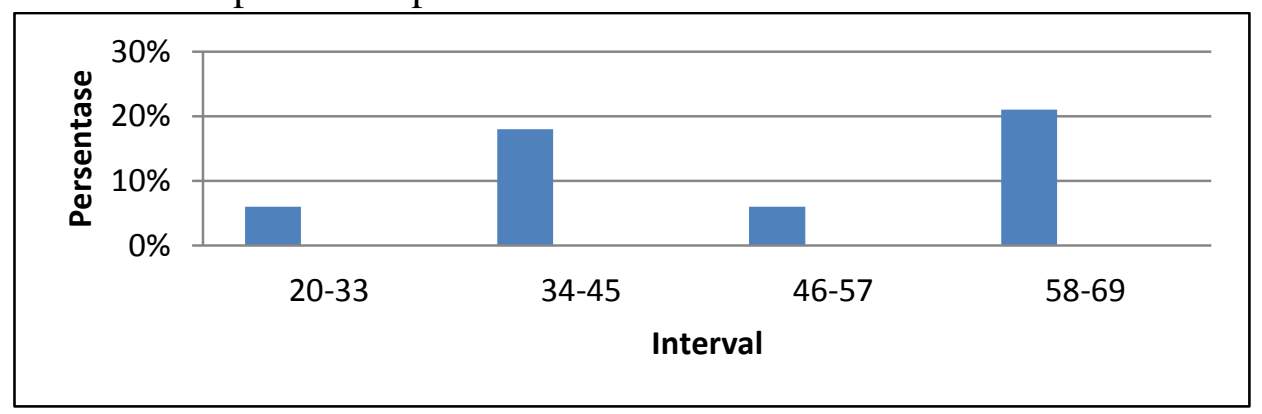

\section{Gambar 1. Distribusi Frekuensi Tes Kemampuan Literasi Siklus I}

Berdasarkan gambar 1 dapat disimpulkan bahwa kriteria penilaian belum mencapai indikator keberhasilan $80 \%$ dari jumlah siswa dengan kriteria "baik". Dari hasil ini maka peneliti akan mengadakan perbaikan pada siklus berikutnya untuk meningkatkan kemampuan kemampuan literasi matematis siswa. Untuk itu guru bersama peneliti merancang kegiatan yang lebih baik atau sesuai dengan kriteria "baik".

\section{b. Hasil Observasi Aktivitas Siswa Siklus I}

Observasi aktivitas siswa masih "cukup baik". Untuk itu diharapkan pada siklus selanjutnya aktivitas siswa meningkat dari siklus I. hal ini menunjukkan bahwa siswa belum berantusias terhadap pembelajaran yang diterapkan oleh peneliti sehingga kualifikasi nilai yang didapatkan berada pada kategori baik dengan persentase nilai $80 \%$.

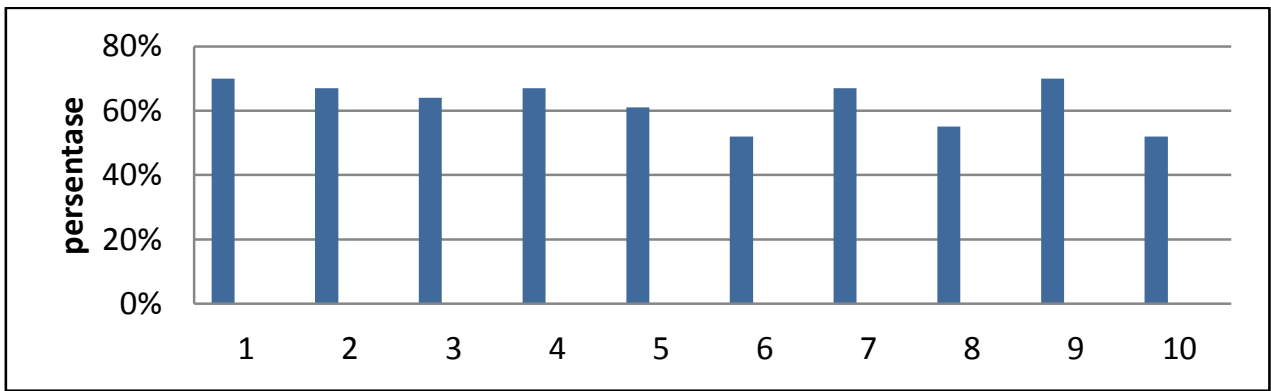

Gambar 2. Servasi Aktivitas Siswa Siklus I

Keterangan:

1. Mempersiapkan buku catatan dan buku pelajaran.

2. Mempersiapkan buku catatan dan buku pelajaran.

3. Mengikuti dengan seksama segala sesuatu yang sedang disampaikan guru.

4. Siswa menyimak pertanyaan atau isu yang terkait dengan pelajaran

5. Siswa berpikir kritis dalam menyimak pertanyaan-pertanyaan atau menjawab pertanyaanpertanyaan yang diajukan guru

6. Memperhatikan dengan sungguh-sungguh, mencatatnya

7. Melakukan diskusi aktif dengan pasangannya

8. Siswa menyelesaikan latihan soal yang diberikan guru.

9. Siswa berani dan aktif dalam mengemukakan pendapatnya

10. Siswa bertanya kepada guru dan siswa lainnya untuk memecahkan masalah tentang materi yang belum dimengerti.

11. Siswa memberikan kesimpulan terhadap materi pembelajaran mikroskopis 
Dari gambar 2 terlihat hasil observasi aktivitas siswa dengan model pembelajaran Problem Centered Learning (PCL) memperoleh 63\% sedangkan aktivitas siswa yang direncanakan dalam penelitian ini adalah $\geq 80 \%$, maka disimpulkan penelitian ini akan dilanjutkan. Jika aktivitas siswa meningkat, maka hasil belajar ataupun kemampuan literasi matematis siswa juga meningkat. Dari hasil yang di dapat guru PTK, peneliti dan observer berdiskusi untuk mendapatkan solusi agar ativitas siswa ini meningkat. Hasil diskusi akan dijadikan perbaikan pada siklus berikutnya.

\section{c. Hasil Observasi Kemampuan Guru Mengelola Pembelajaran Siklus I}

Pengamatan atau observasi juga dilakukan terhadap kemampuan guru mengelola pembelajaran. Observer juga memiliki peran mengamati dan memotret semua aktivitas guru yang terjadi di kelas ketika tindakan dilakukan. Hasil observasi kemampuan guru mengelola pembelajaran disajikan pada gambar 3.

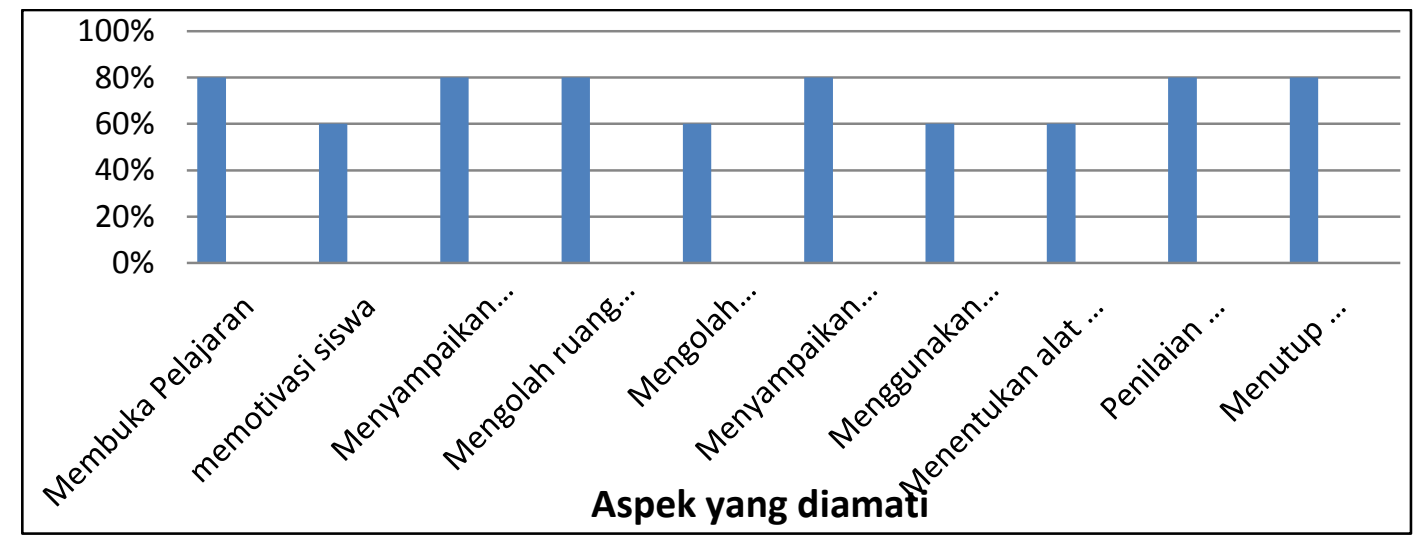

Gambar 3.Kemampuan Guru Mengelola Pembelajaran Siklus I

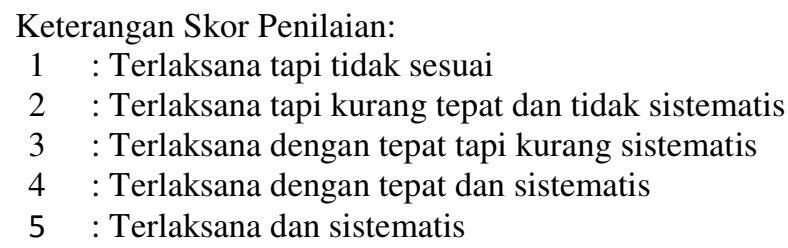

Dari tabel 3, aktivitas guru pada siklus I secara keseluruhan aktivitas guru dengan persentase $72 \%$ dan hal ini menunjukkan kadar aktivitas guru dalam mengelola pembelajaran dengan menerapkan model pembelajaran Problem Centered Learning (PCL) masih berada pada kategori "cukup". Dari hal tersebut beberapa hal yang perlu diperbaiki diantaranya:

a. Penggunaan model pembelajaran Problem Centered Learning (PCL) masih kurang dalam hal pelaksanaannya.

b. Pengelolaan kelas belum maksimal yang mengakibatkan keributan bagi siswa.

c. Penggunaan waktu belum efisien.

\section{Hasil Refleksi Siklus I}

\section{a) Tes Kemampuan Literasi Matematis Siswa}

Pada siklus I hasil refleksi yang ditemukan oleh peneliti pada saat diuji coba dengan 5 butir soal masih banyak siswa yang belum memahami soal dengan baik, siswa cenderung tidak dapat mengemukakan hasil pemikiran dengan tepat, sebagian 
siswa belum mampu menjawab soal sesuai dengan langkah-langkah kemampuan literasi matematis. Hal ini dikarenakan siswa tidak mengerti maksud dan bahasa soal yang diujikan sehingga siswa cenderung malas dalam menyelesaikan soal dan mengosongkan lembar jawaban.

Hasil tes kemampuan literasi matematis siswa diperoleh kemampuan memahami masalah siswa terhadap soal $68 \%$, membuat model matematika dari masalah 66\%, menggunakan konsep, fakta, dan objek dalam matematika untuk menyelesaikan masalah 66\%, menginterpretasikan dan mengevaluasi hasil $55 \%$. Kemampuan literasi matematis siswa pada siklus I siswa yang tuntas hanya $63 \%$. Dari hasil tersebut kriteria penilaian yang telah ditetapkan masih belum terpenuhi $\geq 80 \%$. Maka peneliti akan melanjutkan ke siklus berikutnnya untuk meningkatkan kemampuan literasi matematis siswa.

\section{b) Aktivitas Siswa}

Dari hasil observasi aktivitas siswa terlihat belum dapat mencapai tujuan yang diharapkan. Dari kategori aspek yang dinilai kualifikasi nilai masih cukup. Siswa belum aktif berdiskusi dengan kelompoknya, sebagian siswa hanya diam dan ribut, siswa tidak berani dan aktif dalam mengemukakan pendapatnya, tidak mampu memberikan kesimpulan terhadap materi pelajaran. Hal ini menunjukkan aktivitas siswa masih pasif dalam pembelajaran. Untuk itu pada siklus selanjutnya akan ditingkatkan. Jika aktivitas meningkat, maka hasil belajar ataupun kemampuan literasi matematis siswa akan meningkat.

\section{c) Kemampuan Guru Mengelola Pembelajaran}

Ditinjau dari hasil observasi yang didapat, kemampuan guru mengelola pembelajaran masih cukup, dikarenakan masih merasa ragu dalam menerapkan model pembelajaran Problem Centered Learning (PCL) karena belum terbiasa dengan melaksanakan pembelajaran tersebut, guru belum mampu memberikan motivasi terhadap siswa, kurangnya kemampuan mengolah interaksi belajar dan pembelajaran, menentukan alat dan sumber belajar. Untuk meningkatkan aspek penilaian mengenai kinerja guru tersebut maka akan dilanjutkan ke siklus selanjutnya.I

\section{Deskripsi Hasil Penelitian Tindakan Kelas Siklus II}

Melihat hasil analisis dari penelitian tindakan kelas siklus I diperoleh hasil kemampuan guru mengelola pembelajaran, aktivitas siswa dan kemampuan literasi matematis siswa masih jauh dari persentase yang diharapkan. Sejalan dengan hal tersebut, pelaksanaan model pembelajaran Problem Centered Learning (PCL) belum terlaksana dengan baik. Untuk peneliti kembali melanjutkan penelitian pada siklus II dengan melaksanakan tahap yang sama seperti pada siklus I dengan perbaikan yang direncanakan. Adapun hasil penelitian pada siklus II diuraikan pada gambar 4.

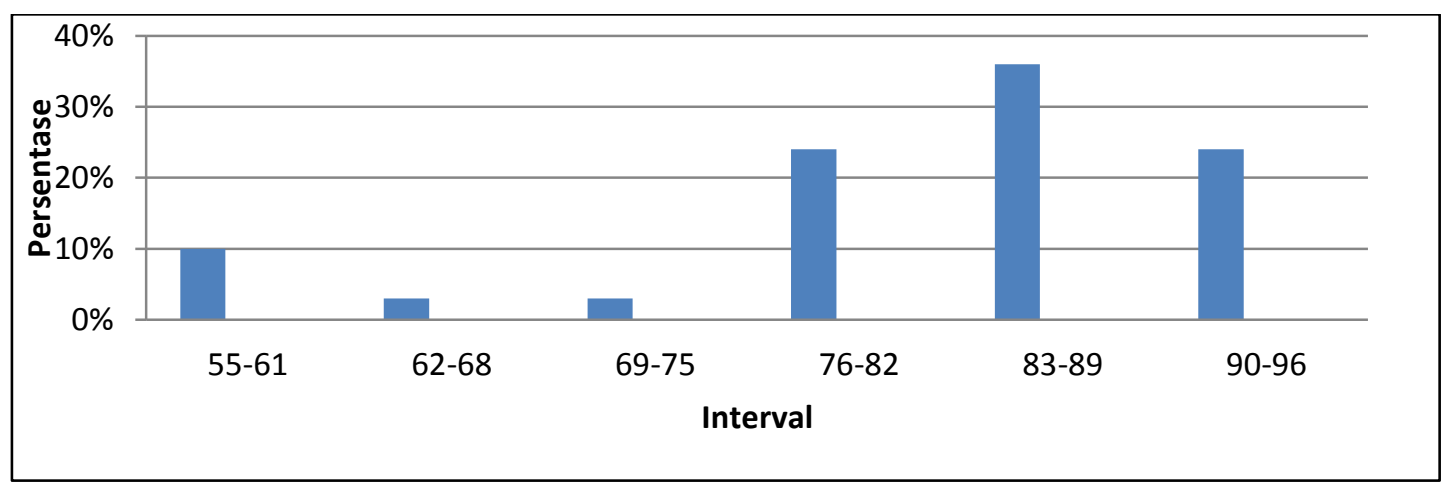




\section{Gambar 4. Distribusi Frekuensi Tes Kemampuan Literasi Siklus II}

Dari gambar 4 secara klasikal diperoleh tingkat kemampuan literasi matematis siswa telah terpenuhi dengan kriteria penilaian yaitu $82 \%$ atau sud 77 mencapai $80 \%$. Dari hasil tersebut maka dapat disimpulkan bahwa kemampu.... literasi matematis siswa mengalami peningkatan jika dibandingkan dengan siklus I. Dilihat dari persentase hasil tes dari siklus I ke siklus II yaitu 20 orang siswa atau $63 \%$ yang mencapai kriteia minimal "baik" menjadi $82 \%$ atau 30 orang siswa.

\section{a. Hasil Observasi Aktivitas Siswa Siklus II}

Hasil observasi terhadap aktivitas siswa dalam pembelajaran selama 3 kali pertemuan pada siklus II ini dapat dilihat pada tabel 5.

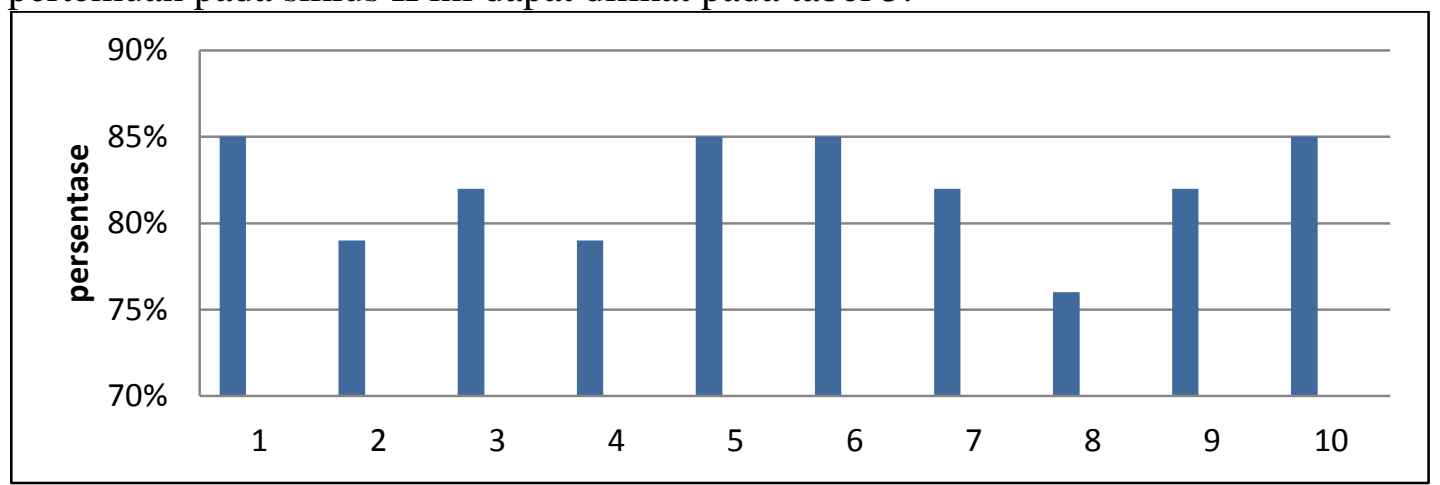

Gambar 5. Observasi Aktivitas Siswa Siklus II

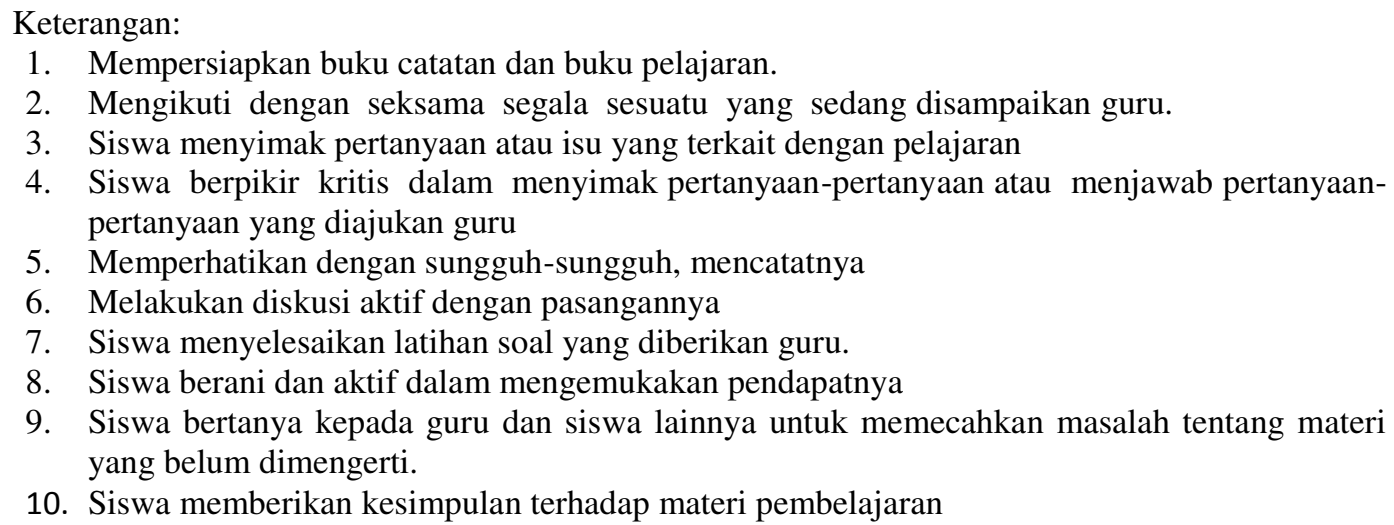

Dari gambar 5 hasil observasi aktivitas siswa dengan model pembelajaran Problem Centered Learning (PCL) dapat dilihat bahwa hasil observasi aktivitas siswa sudah meningkat dengan pembelajaran yang ditetapkan oleh peneliti. Hal ini menunjukkan bahwa siswa berantusias terhadap pembelajaran yang diterapkan oleh peneliti. Sehingga kualifikasi nilai yang didapatkan berada pada kategori "baik" dengan persentase nilai $82 \%$ atau sudah mencapai $80 \%$. Hasil yang didapat sesuai dengan hasil yang diharapkan, maka siklus ini dihentikan.

\section{b. Hasil Observasi Kemampuan Guru Mengelola Pembelajaran Siklus II}

Tingkat kemampuan guru dalam mengelola pembelajaran untuk tiga kali pertemuan dengan persentase kemampuan guru mengelola kelas adalah 94\%. Hal ini berarti guru sudah mulai terbiasa dengan menggunakan model pembelajaran Problem Centered Learning (PCL) dengan baik dan mampu menerapkan model Problem 
Centered (PCL) dalam kegiatan belajar mengajar.Secara keseluruhan kemampuan guru mengelola pembelajaran pada siklus II dapat dilihat pada gambar 6 .

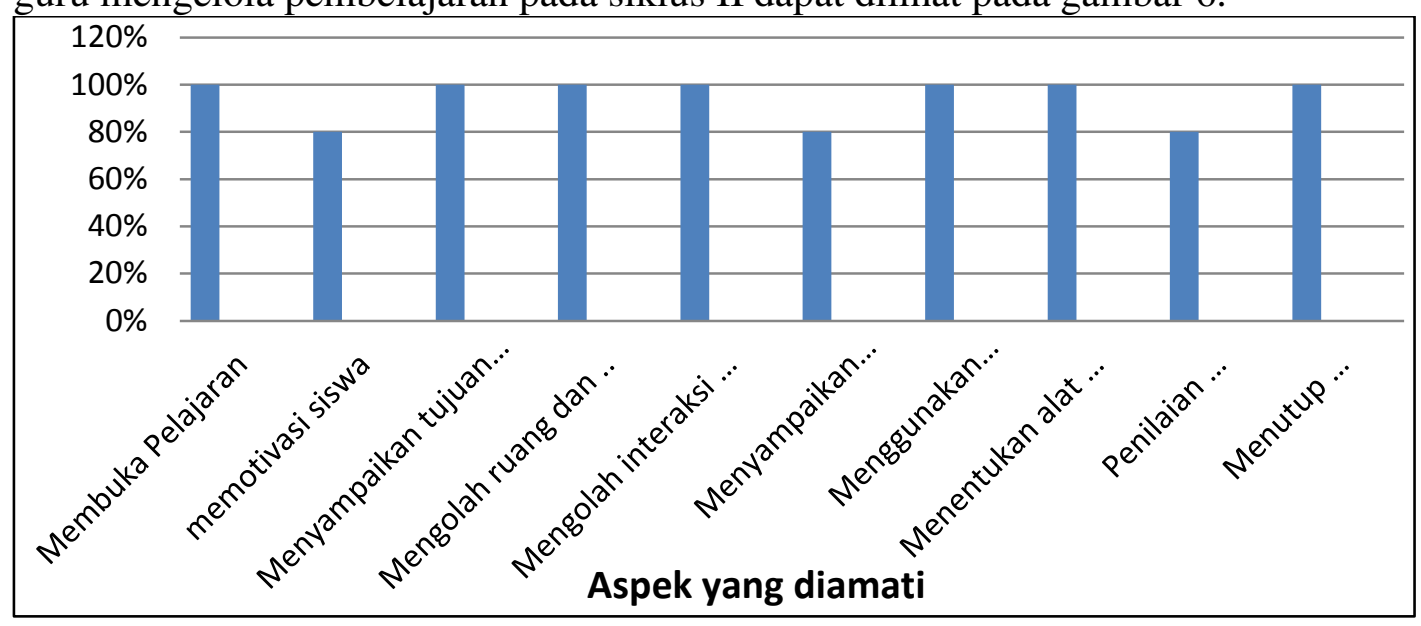

Gambar 6. Kemampuan Guru Mengelola Pembelajaran Siklus II

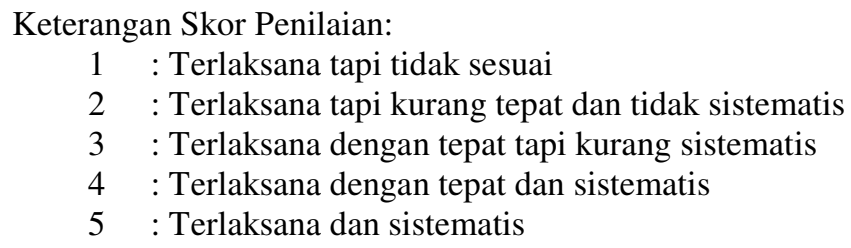

\section{Hasil Refleksi Siklus II}

\section{a) Kemampuan Literasi Matematis Siswa}

Pada siklus II siswa sudah mampu menguasai materi, sudah terbiasa dengan bahasa soal, maksud soal, sudah mampu memahami soal yang diberikan peneliti dengan benar terkait dengan kemampuan literasi matematis siswa. Hasil tes kemampuan literasi matematis siswa diperoleh kemampuan memahami masalah siswa terhadap soal $88 \%$, membuat model matematika dari masalah $83 \%$, menggunakan konsep, fakta, dan objek dalam matematika untuk menyelesaikan masalah 82\%, menginterpretasikan dan mengevaluasi hasil 74\%. Kemampuan literasi matematis siswa pada siklus II siswa yang tuntas $82 \%$. Dari hasil tersebut kriteria penilaian yang telah ditetapkan sudah terpenuhi $\geq 80 \%$. Sehingga penelitian ini dihentikan pada siklus II karena tujuan penelitian sudah tercapai yaitu $80 \%$ dengan kategori "Baik".

\section{b) Aktivitas Siswa}

Jika ditinjau dari segi aktivitas siswa pada siklus II ini, kadar aktivitas siswa lebih baik dari sikulus I. Hal ini terlihat dari hasil observasi aktivitas siswa siklus II, yang memperoleh kategori "Baik". Dilihat dari setiap aspek dalam mengikuti pembelajaran.

Dari uraian di atas, penelitian diberhentikan pada siklus ini karena terlihat aktivitas siswa dalam pembelajaran sudah maksimal. Maka penelitian tidak dilanjutkan lagi karena hasil yang didapat sudah terpenuhi.

\section{c) Kemampuan Guru dalam Mengelola Pembelajaran}

Kemampuan guru mengelola pembelajaran pada siklus II ini di kategorikan "Sangat Baik" dari siklus I. Hal ini terlihat dari hasil pengamatan kemampuan guru mengelola pembelajaran dari siklus I sampai siklus II. Dilihat dari setiap aspek penilaian sudah meningkat menjadi lebih baik, hal ini menunjukkan kadar yang dicapai sudah terpenuhi. Dari uaraian tersebut guru sudah mampu mengelola 
pembelajaran yang diterapkan, sehigga penelitian dihentikan pada siklus II ini karena tujuan penelitian sudah tercapai.

\section{Pembahasan}

\section{Peningkatan Kemampuan Literasi Matematis Siswa}

Peningkatan kemampuan literasi matematis siswa dapat dilihat berdasarkan hasil tes kemampuan literasi siswa pada siklus I terdapat hanya 20 orang siswa yang memperoleh nilai ketuntasan dari 33 siswa yang mengikuti tes atau dengan persentase $63 \%$ dan hasil ini menunjukkan kalau tingkat kemampuan literasi matematis siswa pada siklus I masih berada pada kategori "Cukup". Sedangkan pada siklus II terdapat 30 orang siswa yang memperoleh nilai ketuntasan dari 33 siswa yang mengikuti tes atau dengan persentase $82 \%$ dan hasil ini menunnjukkan kalau tingkat kemampuan literasi matematis siswa pada siklus II telah berada pada kategori baik. Hal ini juga sesuai seperti penelitian kusumah (2010) dan Dwi (2017). Hasil tes kemampuan literasi matematis siswa dari siklus I dan siklus II akan dilihat pada gambar 7.

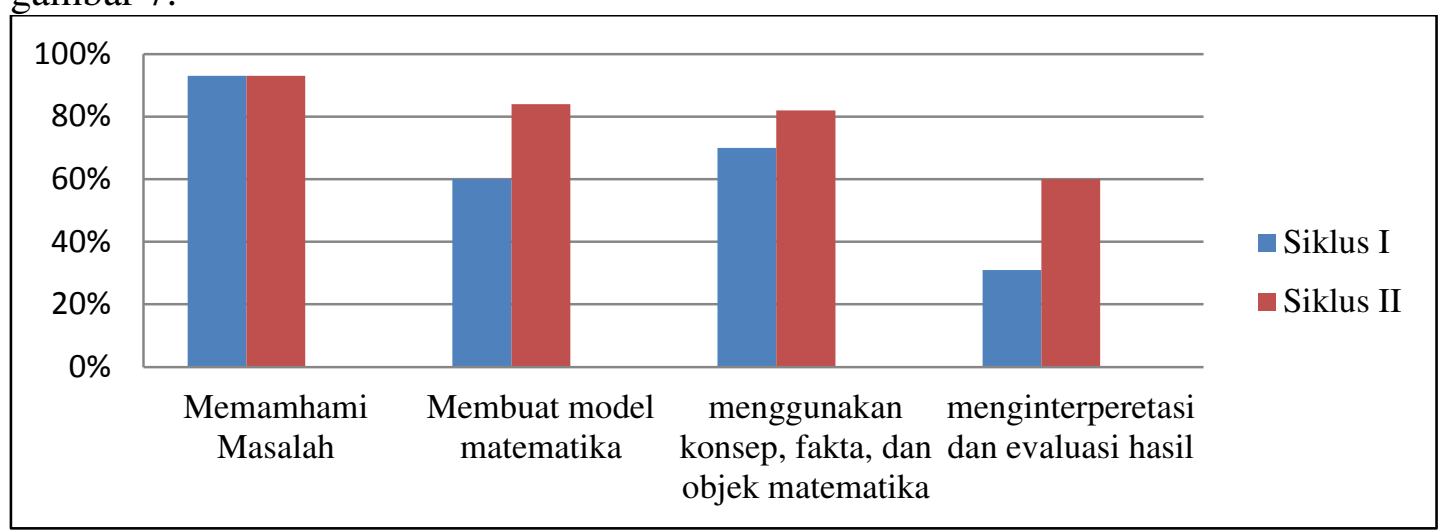

\section{Gambar 7. Peningkatan Hasil Kemampuan Literasi Matematis Siswa}

\section{Peningkatan Aktivitas Belajar Matematika Siswa}

Bila dilihat dari peningkatan aktivitas siswa pada siklus I tidak memenuhi kriteria $80 \%$ yang diharapkan dimana aktivitas siswa pada siklus I hanya mencapai $63 \%$ dengan kriteria cukup, yang dimana aktivitas sisw. Pada siklus II terdapat peningkatan aktivitas siswa menjadi $82 \%$ dengan kriteria "Baik". berarti model pembelajaran Problem Centered Learning (PCL) dapat meningkatkan aktivitas siswa menjadi lbih baik karena dapat meningkatkan kadar aktivitas siswa sesuai pencapaian yang diharapkan. Seperti halnya hasil penelitian Kurniawan (2016).

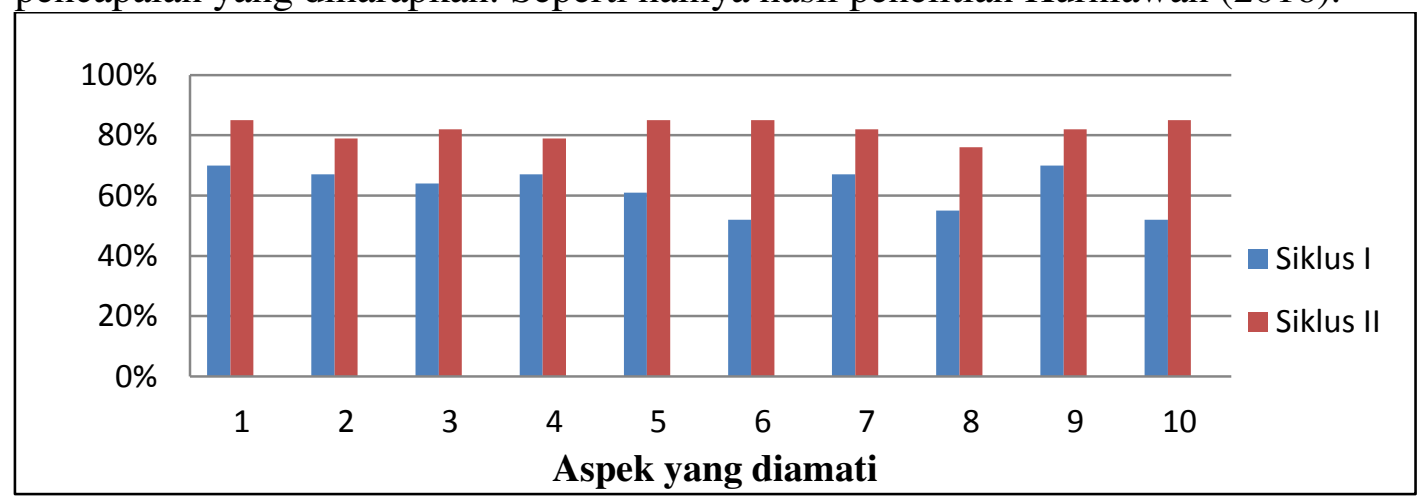

Gambar 8. Peningkatan Hasil Aktivitas Belajar Siswa 


\section{Peningkatan Kemampuan Guru Mengelola Pembelajaran Melalui Model Pembelajaran Problem Centered Learning (PCL)}

Berdasarkan hasil observasi mengelola pembelajaran yang diperoleh dapat di kategorikan dengan baik. lebih jelas dapat dilihat pada gambar 9 .

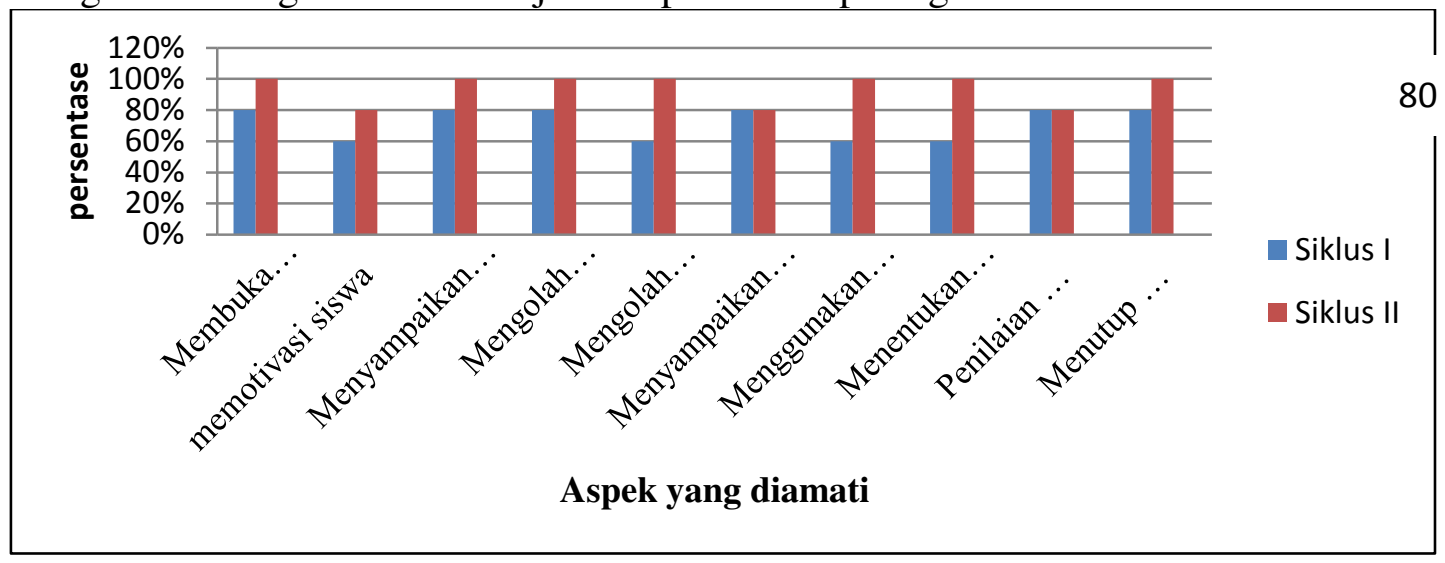

Gambar 9. Peningkatan Kemampuan Guru Mengelola Pembelajaran

Pada diagram tersebut terlihat bahwa kegiatan guru dalam pengelolaan pembelajaran yang diperoleh pada siklus I dengan persentase $72 \%$ dan siklus II $94 \%$ maka terjadi peningkatan $12 \%$. Guru telah mampu menerapkan model pembelajaran tersebut dengan baik.

\section{KESIMPULAN}

Berdasarkan hasil dan pembahasan penelitian, maka pada penelitian ini ditemukan ditinjau dari tingkat kemampuan literasi matematis siswa, setelah pemberian tindakan pada siklus I sebanyak 3 kali pertemuan, siswa diberikan tes, diperoleh sebanyak 20 orang siswa dengan persentase $63 \%$ dari 33 orang siswa pada kategori "cukup baik". Sedangkan 13 orang siswa belum mencapai tingkat yang diharapkan. Bila ditinjau dari segi aktivitas siswa selama tindakan diberikan pada siklus I diperoleh rata-rata kadar aktivitas siswa sebesar 63\% berada pada kategori "Cukup" sehingga .belum memenuhi kriteria yang ditentukan. Hal ini disebabkan belum maksimalnya ssiwa melakukan aktivitas sebagaimana pada aspek-aspek pengamatan. Kemudian selama tindakan pada siklus II diperoleh aktivitas siswa sebesar $82 \%$ berada pada kategori "Baik". Hal ini menunjukkan bahwa kriteria yang diharapkan telah tercapai. Hal ini berarti ada peningkatan dari siklus I ke siklus II. Hasil observasi dari kemampuan guru mengelola pembelajaran selama diberikan tindakan pada siklus I diperoleh kemampuan guru mengelola pembelajaran termasuk pada kategori "Cukup baik" sebesar 72\%. Pada siklus II diperoleh dengan kategori "Sangat baik" sebesar 94\%. Hal ini sesuai dengan kategori yang diharapkan dalam penelitian.

\section{DAFTAR PUSTAKA}

Asri, 2017. Guru Matematika SMA Negeri 1 Angkola Barat. Sitinjak : SMA Negeri 1 Angkola Barat

Dwi, Laili Nur. 2017. Problem Based Learning dengan Strategi Menulis untuk Mengembangkan Kemampuan Literasi Matematika Siswa. Seminar Matematika dan Pendidikan Matematika UNY 2017. ISBN. 978-602-734032-9 
Fathani, A.H. (2016). "Pengembangan literasi matematika sekolah dalam perspektif multiple intelligences", Jurnal EduSains, Vol. 4 (2), pp. 136-150.

Istarani. 2011. 58 Model Pembelajaran Inovatif. Medan. Media Persada.

Kurniawan. 2016. "Pengaruh Model Pembelajaran Problem Centered Learning Terhadap Kemampuan Pemecahan Masalah Matematika Siswa SMK”. Skripsi. FKIP. UNPAS. Bandung.

Kusumah, Y. S. (2010). Literasi Matematis. Bandung: Universitas Pendidi 81 Indonesia. 